九州歯会誌 56 ( 1 ) : 41 50, 2002.

エナメル芽細胞の分化を観察するための培養法の確立

\author{
諸富孝彦 \\ 九州歯科大学歯科保存学第 1 講座（指導：寺下正道教授） \\ 九州歯科大学口腔解剖学第 2 講座（指導：豊島邦昭教授）
}

平成 13 年 12 月 25 日受理

\title{
Establishment of Primary Culture for Observing Ameloblast Differentiation
}

Takahiko Morotomi

Department of Operative Dentistry (Director: Prof. Masamichi Terashita)

Second Department of Oral Anatomy (Director: Prof. Kuniaki Toyoshima)

Kyushu Dental College, Kitakyushu, Japan

The culture system is a very useful method for elucidating differentiation mechanisms of ameloblast which is associated with induction of odontoblast and/or production of enamel matrix. The aim of this study is establishment a primary cell culture system using isolated cervical loop and dental mesenchymal cells in growing end of rat incisors, which make it possible to observe the process of ameloblast cell lineage. To monitor growth and differentiation of epithelial cells, antibodies against cytokeratin 14 and ameloblastin were used as markers of dental epithelial cells and ameloblasts respectively. In this culture, the number of epithelial cells gradually decreased and became $50 \%$ at 10 days. However, all of their remaining cells were ameloblastin expressing cells. When cells were cultured in the presence of skin fibroblasts, they did not express ameloblastin. This culture system is useful for investigation of ameloblast differentiation mechanism in the epithelial-mesenchymal interactions.

Key word: Ameloblast/Differentiation/Cell culture/Cytokeratin 14/Ameloblastin

\section{緒霉}

エナメル質を形成するエナメル芽細胞の増殖分化の調 節機構は，いまだ解明されてはいない，末分化なエナメ ル上皮細胞が，エナメル芽細胞へと分化する過程には各 種調節因子の関与が推測されるが1-4), それらの同定に は, エナメル上皮細胞からエナメル芽細胞への分化過程 を観察しうる細胞培養法が有用である.

Limeback $(1985)^{5)}$ は, ブタ曰歯歯胚より摘出したエ ナメル上皮細胞を，歯乳頭の線維芽細胞様細胞と共培養 し，エナメル基質タンパクであるアメロゲニン ${ }^{6-10)}$ の発現 を報告した. MacDougall ら $(1991,1993,1994)^{11-13)}$ は，
マウス臼蒾茵胚の内エナメル上皮細胞を柬乳頭細胞の非 存在下で培養し、アメロゲニンの発現と石灰化小結節の 形成を報告した. Kukita ら (1992) ${ }^{14)}$ は, ラット切歯歯 胚のエナメル器の細胞を, 無血清培地を用いて培養し, アメロゲニンを発現させることに成功した。 Chen ら $(1992)^{15)}$ はマウス臼歯歯胚のエナメル上皮細胞を用い て,アメロゲニンを発現し続ける不死化エナメル芽細胞 様細胞を樹立した。ささらに Den Besten ら $(1997)^{16)}$ は, ブタ て，アメロゲニンおよびアメロブラスチン ${ }^{17,18)}$ の分泌を 高める培地の条件について報告した。 しかしながら，こ れらの培養法では様々な分化段階のエナメル上皮細胞が 


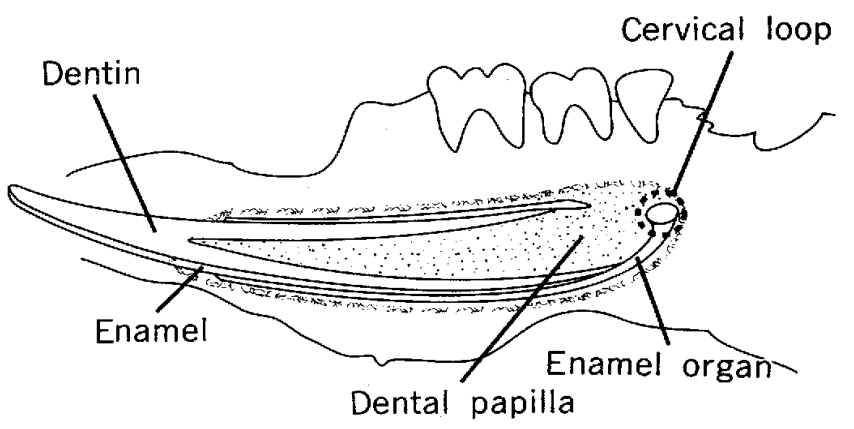

Fig. 1 Schematic appearance of the incisor in a sagittal section through the rat mandible.

混在しているので，どのような因子がェナメル芽細胞の 分化に関わっているかを検討するのには適していない。

ラット切歯エナメル器のサービカルループには（Fig. 1), 組織幹細胞様の特徵を備えた未分化上皮細胞の存在 が報告されている ${ }^{19-21)}$ ：そこでこのサービカルループの エナメル上皮細胞と雬乳頭細胞を用いて, 未分化エナメ ル上皮細胞からエナメル芽細胞への分化を観察しうる培 養法を検討した。

\section{材料および方法}

以下の動物実験は，「九州歯科大学における動物実験 に関する指針」に従い行った。

\section{I . 初代細胞培養}

実験動物には 3 日歯の Wistar 系 SPF ラット（九動） を用いた。麻酔下 (pentobarbital, $40 \mathrm{mg} / \mathrm{kg}$ ) で断頭 後, 無菌下で切霜を傷つけずに摘出し, $2 \%$ Collagenase

(Wako) -Dulbecco's Modified Eagle's Medium Nutrient Mixture F-12 Ham (DMEM/F-12: GIBCO $\mathrm{BRL}$ ) 酵素液に摘出切歯を浸清し， $4{ }^{\circ} \mathrm{C}$ で 8 時間処理し た. 滅菌 Phosphate buffered saline (PBS) 内で歯乳頭 およびエナメル器を, 精密ピンセットを用いて機械的に 分離した後， $26 \mathrm{G}$ 注射針（Termo）を用いて, エナメル 器よりサービカルループ唇側膨隆部を, 歯乳頭から形成 端側をそれぞれ切除した（Fig. 2)。ともにAccumax (Sigma Chemical) で $37^{\circ} \mathrm{C} ， 15$ 分間処理し，ピペッ ティングにて細胞を分散させた. $20 \mu \mathrm{l}$ の培養液中で サービカルループの細胞 $\left(3.0 \times 10^{3}\right.$ 個) と荿乳頭細胞

$\left(1.2 \times 10^{4}\right.$ 個) を混合し, Poly-L-Lysin-coated cover glass $12 \mathrm{~mm}$ type (IWAKI) 上に播種した. またサービ カルループ細胞 $\left(3.0 \times 10^{3}\right.$ 個) とヒ卜雬肉由来線維芽細 胞 (ヘルシンキ宣言に準拠) $\left(1.2 \times 10^{4}\right.$ 個) を混合し, 同 様に播種した。 さらに歯乳頭細胞 $\left(1.2 \times 10^{4}\right.$ 個 $)$ のみの

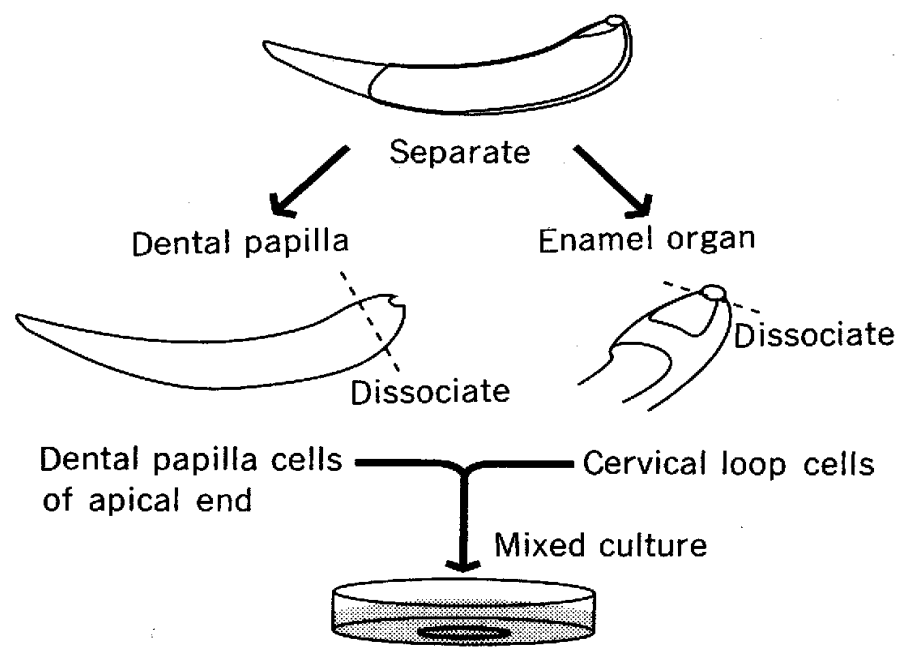

Fig. 2 The method of the cervical loop cells and dental papilla cells.

培養も行った。

細胞を播種してから 2 時間後, 細胞がカバーグラス上 に定着したことを確認し， $1 \mathrm{ml}$ の液体培地を加え $37^{\circ} \mathrm{C}$, $5 \% \mathrm{CO}_{2}$ 下で培養した。培地は $\mathrm{DMEM} / \mathrm{F}-12$ に $10 \%$ Fetal bovine serum (Valley Biomedical), $100 \mathrm{IU} / \mathrm{ml}$ Penicillin and $100 \mu \mathrm{g} / \mathrm{ml}$ Streptomycin (GIBCO BRL), $100 \mu \mathrm{g} / \mathrm{ml}$ Ascorbic acid (Sigma Chemical), $2 \mathrm{mM}$ L-glutamine (GIBCO BRL), $500 \mu \mathrm{M} \beta$-glycerophosphate（Sigma Chemical）を添加したものを使 用し，2 日ごとに交換した。

II. 免疫組織化学的染色法

A. 組織切片の免疫染色

1 日齢の Wistar 系 SPF ラットを麻酔下（pentobarbital, $40 \mathrm{mg} / \mathrm{kg}$ ) で断頭, 下顎を摘出し O. C. T. Compound（SAKURA）に浸漬後，急速凍結した，厚さ $10 \mu \mathrm{m}$ で凍結切片を作製し， $4 \%$ paraformardehyde (PFA：Merck KgaA)/PBSに 30 分浸漬固定した後, $1.5 \%$ Goat serum (Vector Laboratories) /PBS で 30 分間ブロッキングし, 免疫染色に供した.

1 次抗体には 200 倍に希釈したマウス由来モノクロー ナル抗サイトケラチン 14 抗体 (NCL-LL002 NOVO CASTRA）と，2000倍に希釈したウサギ由来ポリク ローナル抗アメロブラスチン抗体（広島大学, 内田隆教 授より供与された）を用いて，室温で 2 時間反応させた。 2 次抗体には 200 倍に希积したヤギ由来抗マウス IgGAlexa Fluor 546 (Molecular Probes) と 200 倍に希釈 したヤギ由来抗ウサギ IgG-Alexa Fluor. 488 (Molecular Probes）を用い，室温で 1 時間反応させた。すずて 
の抗体の希釈には $1.5 \%$ goat, serum/PBS を用いた。 染色後, 蛍光顕微鏡（BX60：OLYMPUS）にて観察 した.

B. 培養細胞の免疫染色

培養細胞は $4 \% \mathrm{PFA} / \mathrm{PBS}$ で 20 分間固定後， $0.1 \%$ Polyoxyethylene (10) Ocylphenyl Ether (Wako) / PBS を用いて室温で 5 分間処理し，組織染色と同様に免 疫染色を行い観察した。

\section{結果}

I .ラット切柬柬胚におけるサイトケラチン 14 およ びアメロブラスチンの発現

1 日齢ラットの下顎切歯歯肧に招けるサイトケラチン 14 およびアメロブラスチンの発現を, 免疫組織化学的手 法を用いて検索した。

A. サイトケラチン 14 の発現

サービカルループよりエナメル芽細胞へ至るす心゙ての エナメル上皮細胞で，その発現が確認された（Fig. 3a).
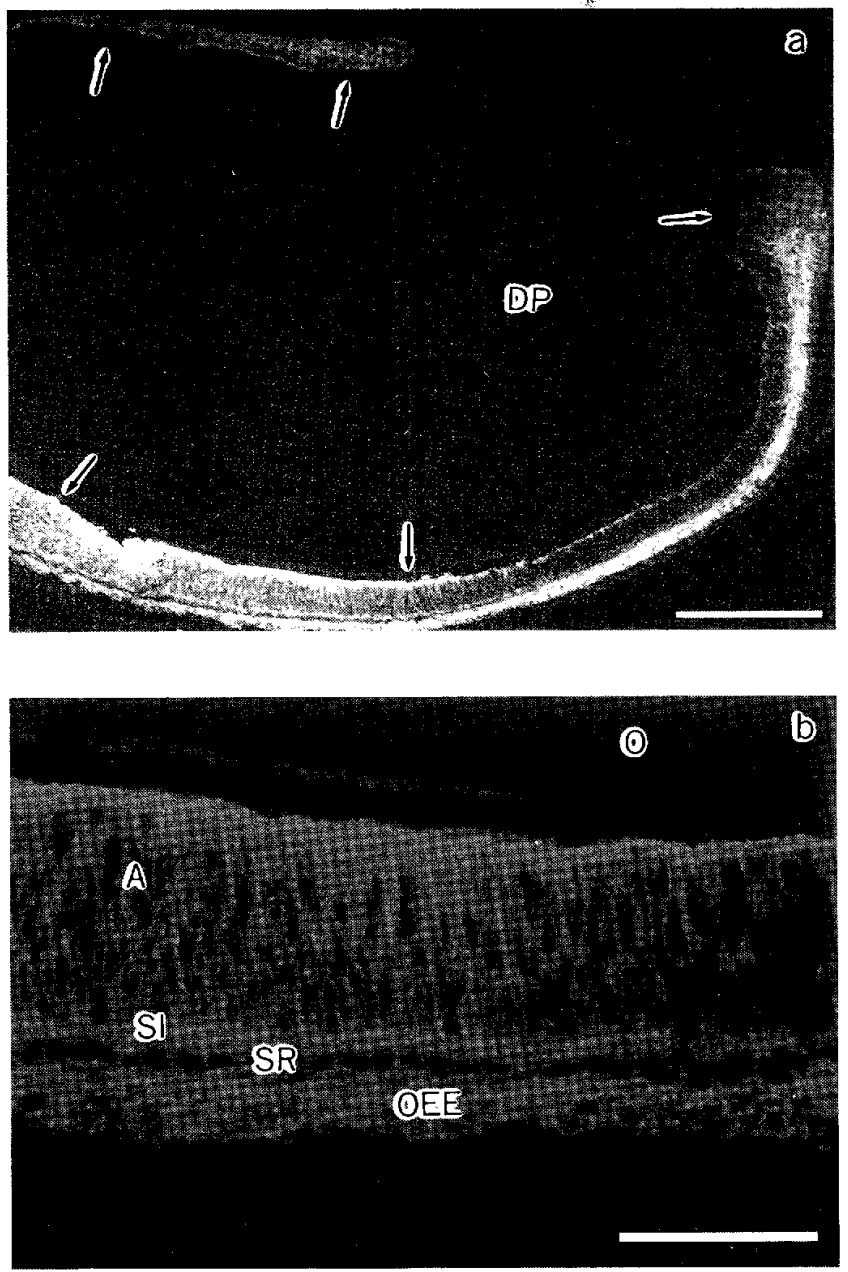

細胞内のサイトケラチン 14 の局在は, 細胞により 2 種 に分けられた，星状網細胞や中間層細胞，外エナメル上 皮細胞，そしてエナメル芽細胞では，細胞質全体でフィ ラメント状に発現が認められ（Fig. 3b), 一力サービカ ルループの基底膜側の細胞と内エナメル上皮細胞では, 細胞膜側の細胞辺緣部でのみ発現が見られた（Fig. 3c）.

B. アメロブラスチンの発現

アメロブラスチンの発現は特異的にエナメル芽細胞で 認められ，細胞内での発現は象牙質側（分泌極側）で顆 粒状に見られた（Fig. 4a，b）。他のエナメル上皮細胞や 間葉細胞では，発䚅を認めなかった（Fig. 4a-d）。

II . 培養エナメル上皮細胞の経日的観察

A. ラット切歯歯胚のサービカルループ細胞と歯乳頭 細胞の共培養

3 日齿ラットの切雬歯胚より得たサービカルループの 細胞を, 形成端側の蒾乳頭細胞と共培養し, 免疫細胞化 学的手法を用いてサイトケラチン 14 とアメロブラスチ ンの発現を経日的に確認した。

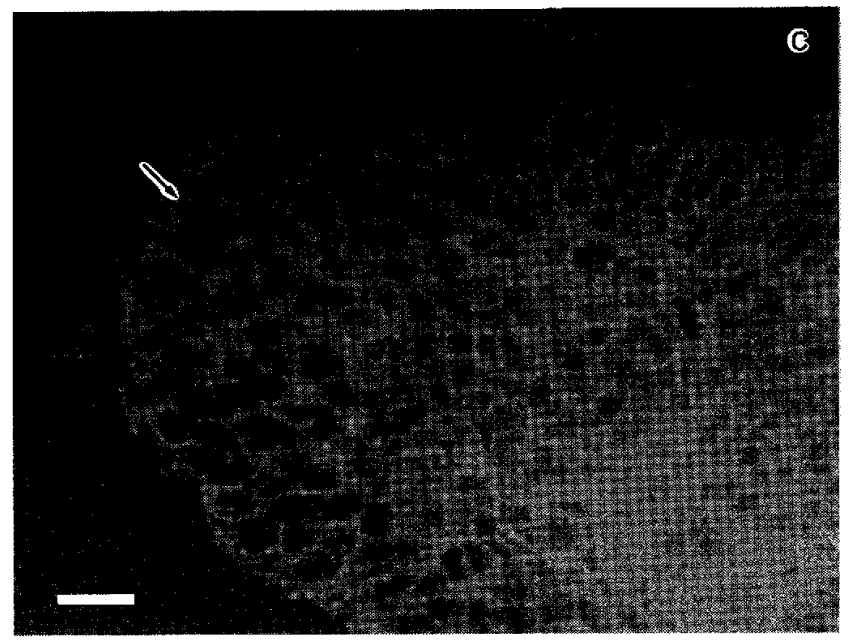

Fig. 3 Localization of cytokeratin 14 in the postnatal 1 day rat lower incisor tooth germ. Sagittal sections.

a : The apical end of the lower incisor. All epithelial cells express cytokeratin 14 (arrow head).

b : Higher magnification of ameloblasts.

c : Higher magnification of the cervical loop. Cervical loop cells adjacent to basement membrane are stained weakly (arrow).

DP : dental papilla

$\mathrm{O}$ : odontoblasts

A : ameloblasts

Bars: (a) $200 \mu \mathrm{m}$; (b and c) $50 \mu \mathrm{m}$. 

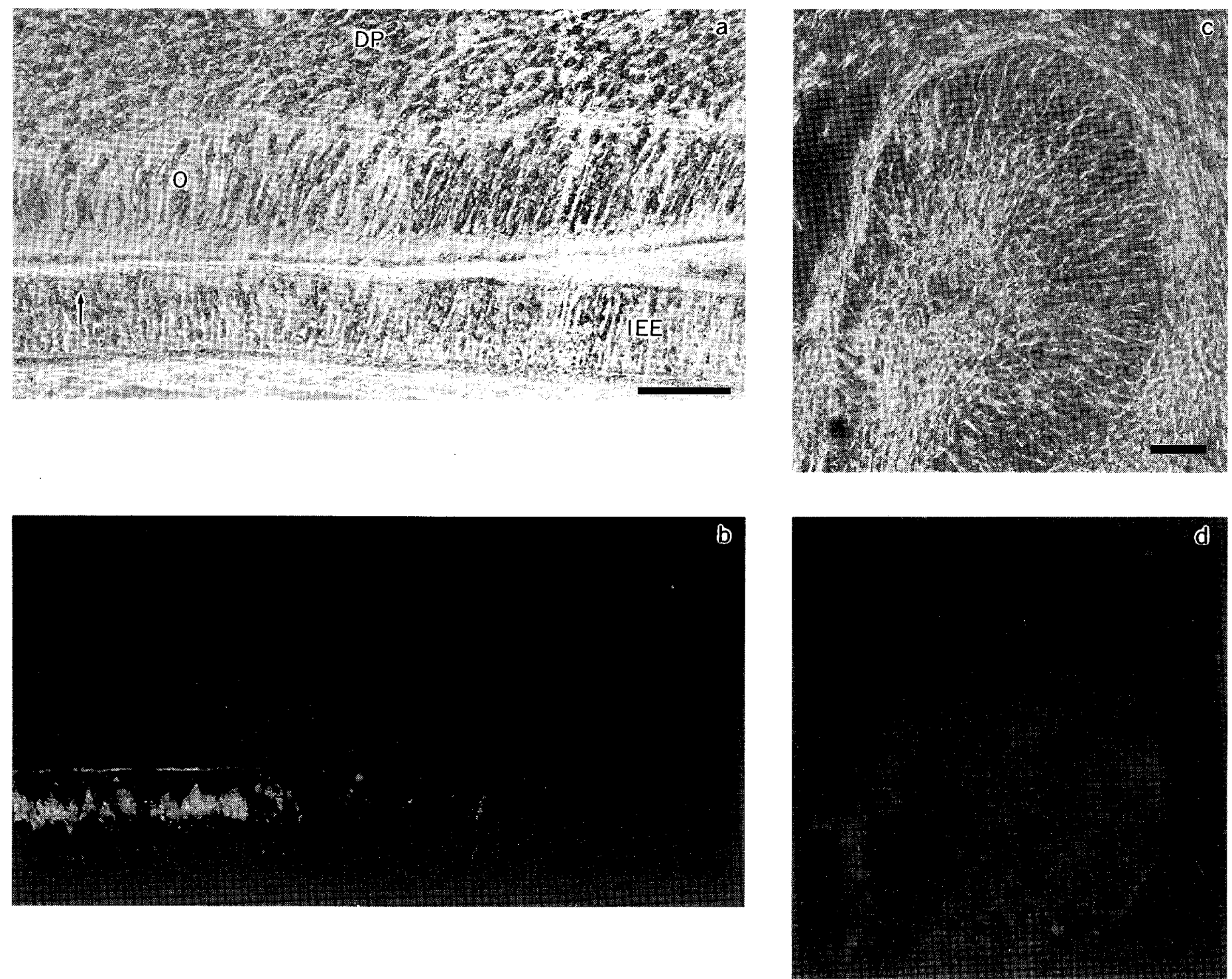

Fig. 4 Localization of ameloblastin in the postnatal 1 day rat lower incisor tooth germ. Sagittal sections.

a : Phase-contrast micrographs of ameloblasts.

b : Ameloblastin is expressed in ameloblasts.

c : Phase-contrast micrographs of cervical loop.

$\mathrm{d}$ : Ameloblastin is not detected in the cervical loop cells.

DP : dental papilla

$\mathrm{O}$ : odontoblasts

A : ameloblasts

IEE : inner enamel epithelium

Bars : $50 \mu \mathrm{m}$.

\section{1.サイトケラチン 14 陽性細胞}

細胞播種直後に免疫染色を行い, サイトケラチン 14 を発現するエナメル上支細胞が，歯乳頭細胞中に散在し ていることを確認した. 培養 2 日目以降, サイトケラチ ン 14 陽性細胞の数は培養日数の経過とともに減少し, 10 日目には播種時のおよそ半数となった（Fig. 6a).

\section{2.アメロブラスチン陽性細胞}

細胞播種直後には, アメロブラスチン陽性細胞は観察 されなかった，培養 2 日目, サイトケラチン 14 陽性細胞 の中にアメロブラスチンにも陽性を示す細胞が出現した が, その数は極めて少なく $(0.53 \%)$, 染色程度も非常 に弱かった（Fig. $5 \mathrm{a}-\mathrm{c}$ ). 培養 4 日目では発現細胞がわ 

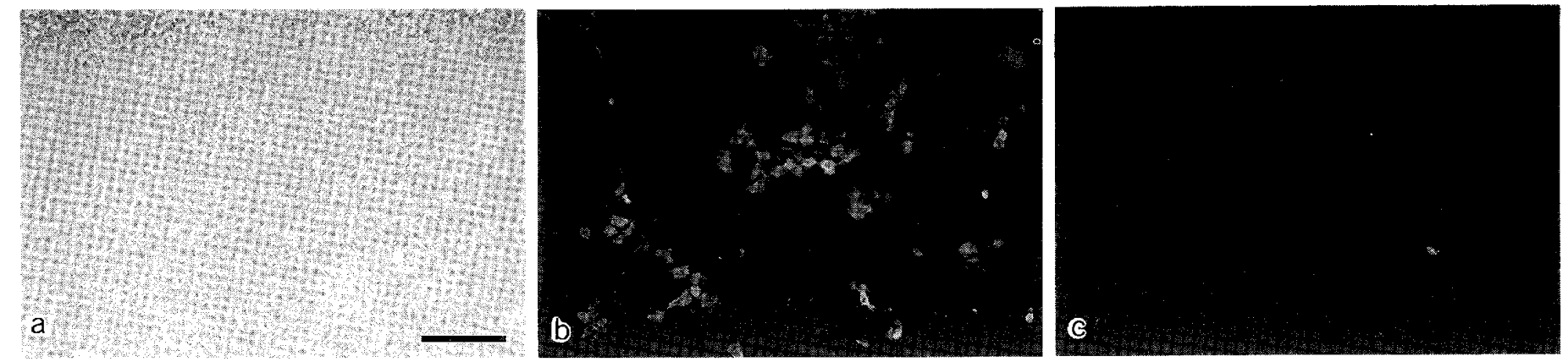

d
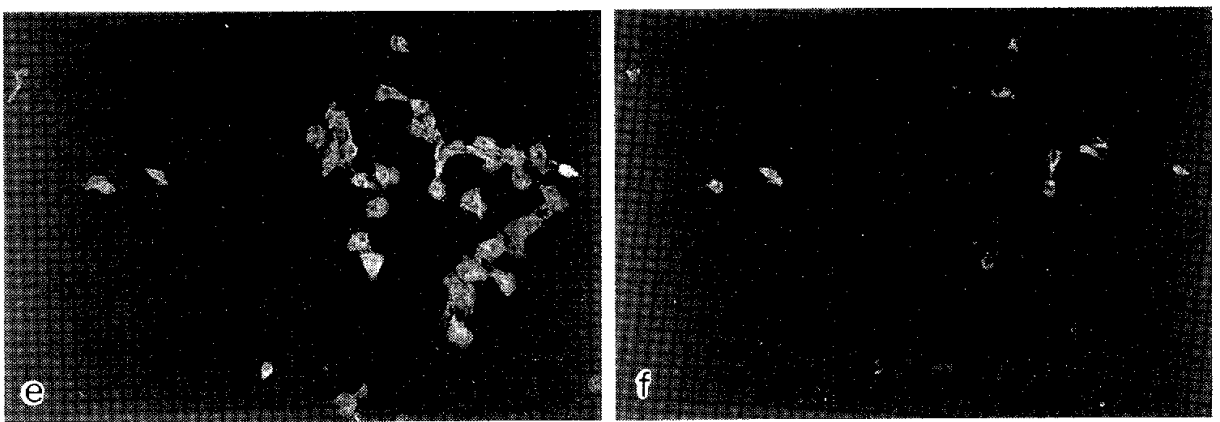

g
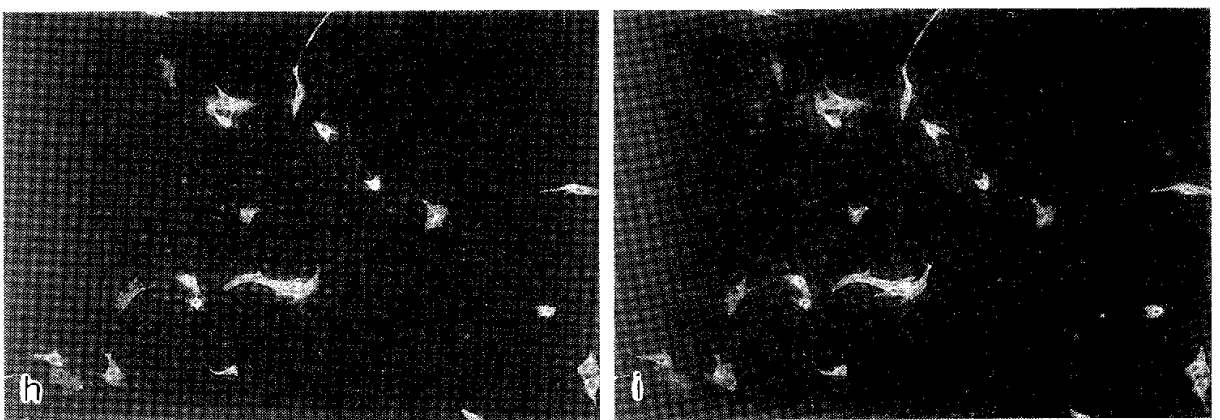

Fig. 5 Immunocytostaining for cytokeratin 14 and ameloblastin in culture of cervical loop cells and dental papilla cells.

a-c: 2 days culture. Cytokeratin 14 positive cells (b) and ameloblastin positive cells (c).

$\mathrm{d}-\mathrm{f}$ : 4 days culture. Cytokeratin 14 positive cells (c). Ameloblastin positive cells are detected, however the degree of staining is weak (f).

g-i : 10 days culture. All cytokeratin 14 positive cells (h) express ameloblastin (i).

a, d, g: Phase-contrast micrographs

Bars : $200 \mu \mathrm{m}$.

ずかに増加したが $(2.8 \%)$ ，染色性の変化は認めな かった（Fig. 5d-f)。しかし培養6日目にはアメロブラ スチン陽性細胞の数は急増し，その染色性屯増強した (Fig. 6a).このときサイトケラチン 14 陽性細胞中, $73 \%$ アメロブラスチン陽性を示した. 6 日目から 10 日目までは，アメロブラスチン陽性細胞の数はほとんど 変化しなかった (Fig. $5 \mathrm{~g}-\mathrm{i})$. 培養 10 日目にはアメロブ ラスチンの発現は細胞質全体に，顆粒状に認められた (Fig. 7a， b). サイトケラチン 14 陽性細胞のうちアメ ロブラスチン陽性細胞の割合は，4 日目から6日目の間 に顕著に増加した（Fig.6b）。これは，サイトケラチン 14 陽性細胞の減少にも関わらず, アメロブラスチン陽性
細肘が急增した結果である。10日目には，ほとんよ゙すべ てのサイトケラチン 14 陽性細胞がアメロブラスチンに も陽性を示すようになった（Fig. 6b），培養期間中のす ベてのアメロブラスチン陽性細胞は, サイトケラチン 14 にも陽性を示した。

共培養と同時に，形成端の柬乳頭細胞のみの培養も行 い, 歯乳頭細胞中にはエナメル上皮細胞の混入がないこ とを確認した (Fig. $8 \mathrm{a}-\mathrm{c})$.

B. ラット切歯霜胚のサービカルループ細胞とヒト皮 膚由来線維芽細胞との共培養

3 日齢ラットの切蒾柬胚より得たサービカルループ細 胞を, ヒト皮膚由来線維芽細胞と共培養し, サイトケラ 

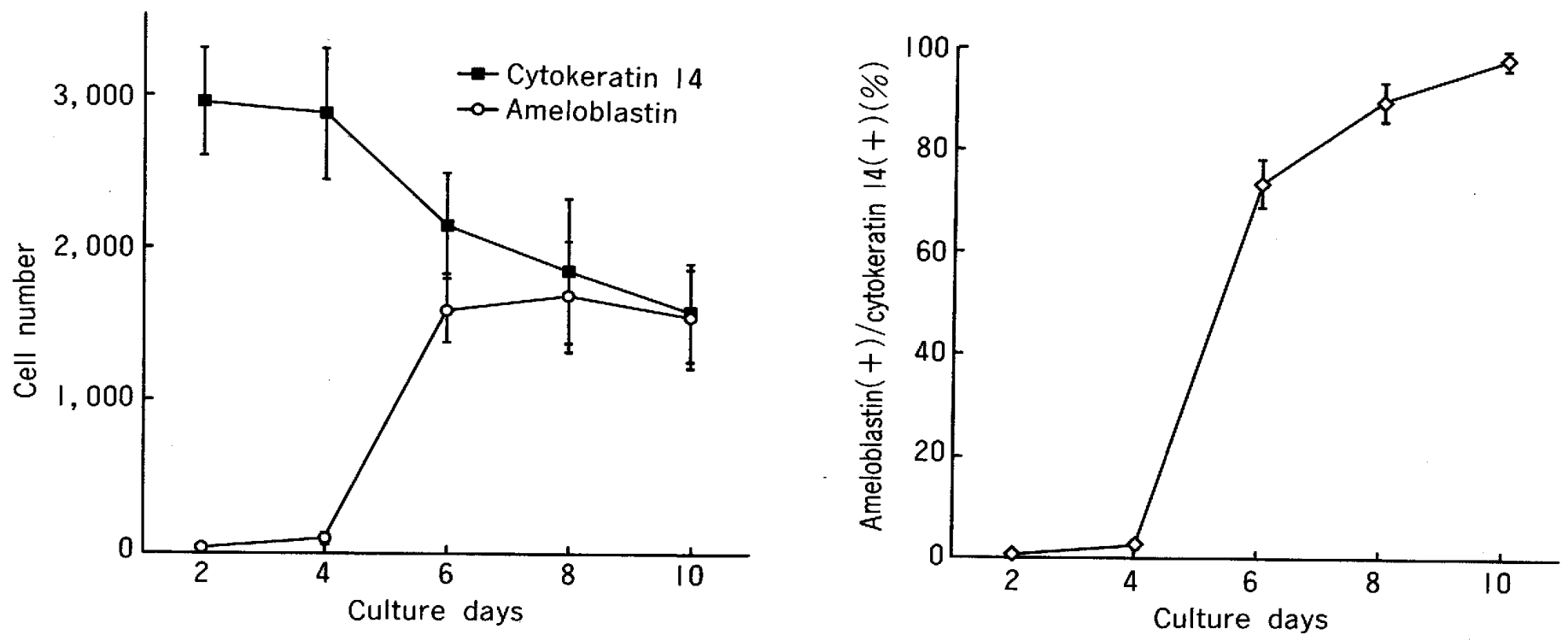

Fig. 6 Change of the cytokeratin 14 and ameloblastin positive cells.

a : Change the number of cytokeratin 14 and ameloblastin positive cells. While cytokeratin 14 cells gradually decrease for 10 days culture, ameloblastin positive cells increase between 4 and 6 days distinctively.

$\mathrm{b}$ : The change of the rate of cytokeratin 14 positive cells expressing ameloblast time-dependently. The value is increased between 4 and 6 days distinctively, and almost all cytokeratin 14 positive cells express ameloblastin at 10 days.
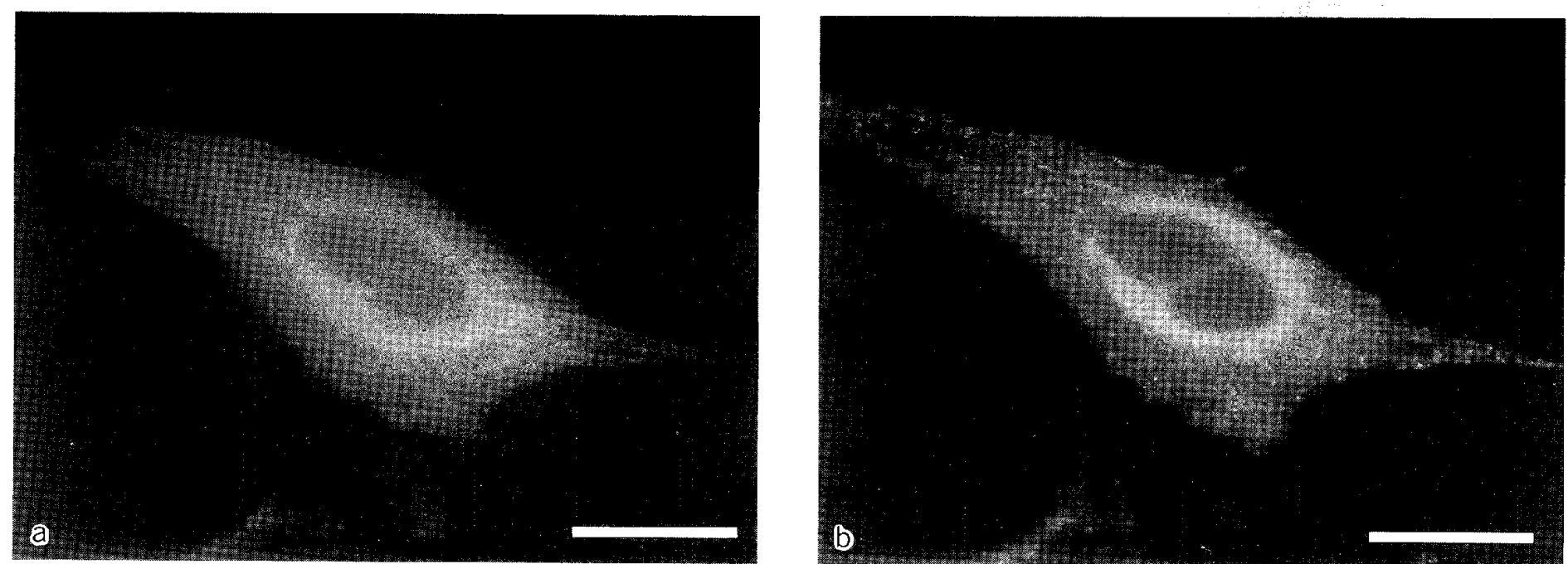

Fig. 7 Higher magnification of cervical loop cells after 10 days culture.

a : The expression of cytokeratin 14 is fibriform appearance.

b : The expression of ameloblastin is granular appearance.

Bars : $20 \mu \mathrm{m}$. 

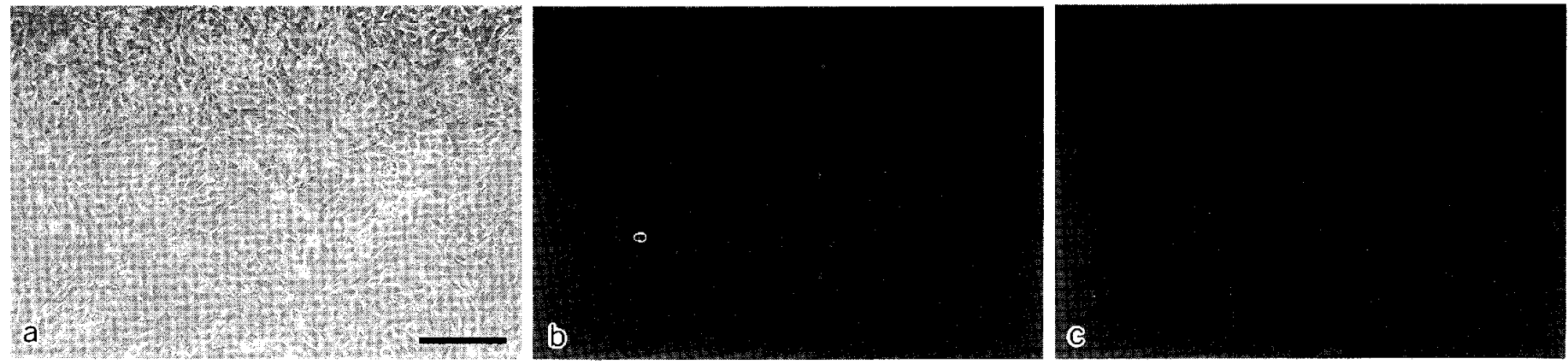

Fig. 8 Dental papilla cells at 10 days.

Cytokeratin 14 (b) and ameloblastin (c) positive cells were not appeared.

Bar : $200 \mu \mathrm{m}$.
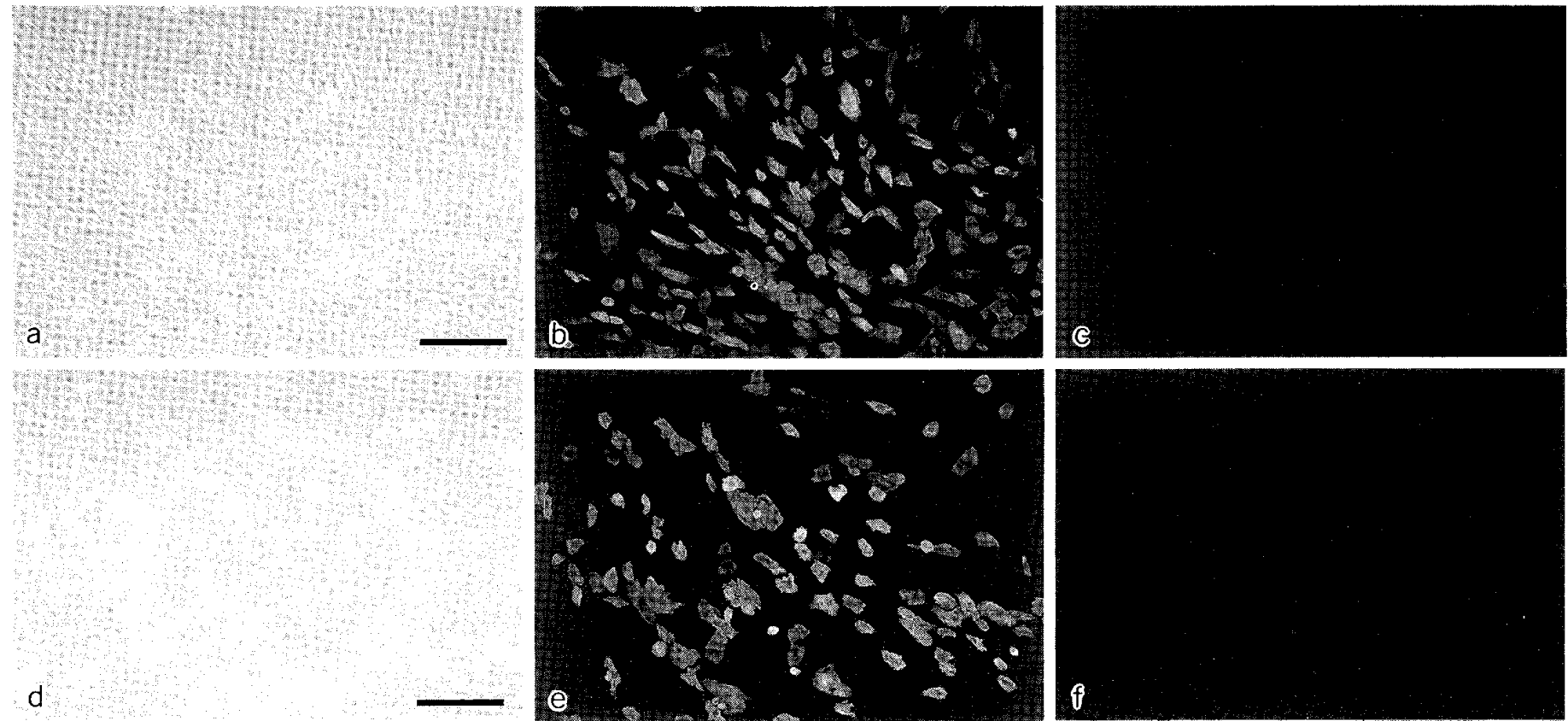

Fig. 9 Cytokeratin 14 and ameloblastin expression in the culture of cervical loop cells and skin fibroblasts.

b, e: Expression pattern of cytokeratin 14 .

$c, f$ : Expression pattern of ameloblastin.

a, d: Phase contrast micrographs.

$\mathrm{a}-\mathrm{c}: 2$ days culture.

d-f : 10 days culture. While cytokeratin 14 positive cells was appeared, both ameloblastin and cytokeratin 14 positive cells were not.

Bars : $200 \mu \mathrm{m}$.

チン 14 およびアメロブラスチンの発現を観察した。本 実験であ培養 2 日目より 10 日目まで，それぞれの発現 を確認した，培養期間中すべての日数において，サイト ケラチン 14 陽性細胞は多数認められたが, アメロブラ スチン陽性細胞は出現しなかった（Fig.9a-f）.

\section{考 察}

エナメル質形成は，エナメル上皮細胞のエナメル芽細 胞への分化，その後のエナメル基質タンパクの分泌，さ らに石灰化亡続く一連の現象である.このエナメル質形 成機構を解明する目的で，現在まで各種のエナメル上皮 細胞培養法が考案されている，しかしこれまでに，未分 
化な上皮細胞を単離，培養し，エナメル芽細胞への分化 を確認したという報告はなされていない，そこで本実験 では, ラット切霜サービカルループに存在する未分化な エナメル上皮細胞を用いて, エナメル芽細胞への分化を 観察しうる培養法を確立し, その過程を観察した。

本研究では, 培養継胞のエナメル上皮マーカーとし て，サイトケラチン 14 を用いた。 サイトケラチン 14 は, 表皮や口腔粘膜上皮の中間径フィラメントを構成するサ イトケラチンポリペプチドの 1 種であり ${ }^{22), ~ エ ナ メ ル 上 ~}$ 皮にあ発現することが報告されている 切歯歯有におけるサイトケラチン 14 の発現は，すべて のエナメル上皮細胞で認められ (Fig. 3), Tabata ら $(1996)^{26)}$ や Domingues ら $(2000)^{27)}$ の報告之同様で あった．エナメル芽細胞の分化マーカーには，アメロブ ラスチンを用いた. エナメル基質タンパクは, その $90 \%$ がアメロゲニンより構成され28)，それについでアメロブ ラスチンの含有量が多い17,299. これまで培養細胞におけ るエナメル芽細胞の分化マーカーとしてはアメロゲニン が多く用いられてきたが, Inai ら (1991) ${ }^{30)}$ やNakamura ら $(1994)^{31}$ は, その免疫染色が歯乳頭細胞でも検 出されることを報告している，1 日齿ラット切歯歯胚で のアメロブラスチンの発現を観察したが, Krebsback ら (1996) ${ }^{17)}$ の報告と同様に, 分化したエナメル芽細胞 のみに特異的に認められた (Fig. 4).この結果より, 了 メロブラスチンはエナメル芽細胞のマーカーとして，ア メロゲニンよりあ有用であると考えられる.

Kukita ら $(1992)^{14)}$, Chen ら (1992) ${ }^{15)}$, そしてDen Besten ら (1997) ${ }^{16)}$ はエナメル上皮細胞の単独培養に よりエナメル基質タンパクが発現することを報告してい るが，これらの培養では様々な分化段階のエナメル上皮 細胞が混在しており，末分化なエナメル上皮細胞のエナ メル芽細胞への分化過程を観察する方法としては適して いない. 一方, 本研究では組織幹細胞様のエナメル上皮 細胞が存在するとされるサービカルループの細胞のみを 用いることで ${ }^{20)}$, アメロブラスチンを発現する細胞が出 現し，増加する過程を観察できた。

本培養法ではエナメル上皮細胞の增殖は認められず, 10 日後には半数に減少する (Fig. 6 a). Harada ら $(1999)^{20)}$ は，サービカルループに存在している組織幹 細胞様細胞の維持には，周囲の歯乳頭細胞より分泌され る線維芽細胞增殖因子 (FGF)-10 が必要であることを 報告している，歯乳頭細胞より分泌された FGF-10 は, 基底膜のへパラン硫酸プロテオグリカンに濃䆶された上 でサービカルループの細胞に効果を与えると考えられて
いる32． 本培養法ではコラゲナーゼによって基底膜を消 化した結果, 間葉細胞の発現した FGF-10 は拡散すると 考えられ, そのため効果的に作用せず，サービカルルー プの細胞の多くはアポトーシスに陥ったと考えられる。 しかしながら歯乳頭細胞の作用で分化の方向性を獲得し た細胞はアポトーシスには陥らず, 生存したと推測す る.

サービカルループの細胞を形成端側㐘乳頭細胞と共培 養し，生存し続けた上皮細胞は，10日目までにすべてが アメロブラスチン陽性を示した（Fig. 5，6)。一方，サー ビカルループの細胞を皮膚線維芽細胞と共培養すると, アメロブラスチン陽性細胞は出現しなかった ${ }^{14}$. このこ とから，エナメル芽細胞への分化誘導には, 歯乳頭細胞 の存在が必要であることが示唆される.これまでに，歯 の発生における上皮組織と間葉組織の相互作用の重要性 と, それに関与する多種の成長因子や細胞外基質タンパ ク, 転写因子が報告されている 頭細胞が未分化エナメル上皮細胞をエナメル芽細胞へと 分化させることを確認した. 今後, 蒾乳頭細胞とサービ カルループの細胞との相互作用による増殖と分化の機構 の解明に，ここに確立した培養法は有用であると考えら れる。

\section{結論}

本研究では未分化エナメル上皮細胞の，エナメル芽細 胞への分化を in vitro で観察が可能となる培養法を確立 し, 以下の結論を得た.

I 、ラット切歯サービカルループには, エナメル芽細 胞への分化能を保持する㳖分化エナメル上皮細胞が存在 する.

II.ラット切歯サービカルループに存在する未分化上 皮細胞が， in vitro でエナメル芽細胞へと分化するため には, 歯乳頭細胞の存在が必要である.

III. サービカルループの未分化上皮細胞を分散し, 歯 乳頭細胞集団中で培養すると増殖はせず，生存したすべ ての上皮細胞がエナメル芽細胞へと分化する.

以上の結果より, 本培養法はエナメル器の未分化エナ メル上皮細胞の，エナメル芽細胞への分化を in vitro で 再現しうる方法であり, エナメル上皮細胞の堌殖や分化 に関わる因子を解明する上で, 有用な実験法であること が示された。

稿を終えるにあたり, 終始懇篤なる御指導, 御校閲の 労を賜りました九州歯科大学歯科保存学第 1 講座寺下正 
道教授および口腔解剖学第 2 講座豊島邦昭教授に深甚な る感謝の意を表します.またご懇切な御助言, 御指導下 さいました口腔解剖学第 2 講座原田英光助教授, 貴重な 抗体を御供与頂きました広島大学歯学部内田隆教授に謹 んで感謝の意を表します。さらに，奏験の遂行に御協力 を賜りました歯科保存学第 1 講座ならびに口腔解剖学第 2 講座の皆様に, 厚く御礼申し上げます.

本研究の一部は平成 13 年度九州雨科大学後援会大学 院生研究援助費により, また加藤記念バイオサイエンス 研究振興財団の補助のもとに行われた.

本研究の要旨は, 第 43 回歯科基礎医学会学術大会 (2001 年 9 月 19 日, さいたま), 第 115 回日本歯科保存 学会秋季学会（2001 年 11 月 9 日, 福岡) で発表した。

\section{引用文献}

1) Peters, H. and Balling, R.: Teeth where and how to make them. Trends Genet. 15: 59-65, 1999.

2) Jernvall, J. and Thesleff, I.: Reiterative signaling and patterning during mammalian tooth morphogenesis. Mech. Dev. 92 : 19-29, 2000.

3) Zechner-David, M., Diekwisch, T., Fincham, A., Lau, E., MacDougall, M., Morakian-Oldak, J., Simmer, J., Snead, M. and Slavkin, H. C.: Control of ameloblast differentiation. Int. J. Dev. Biol. 39: 69-92, 1995.

4) Ahamad, N. and Ruch, J. V.: Comparison of growth and cell proliferation kinetics during mouse molar odontogenesis in vivo and in vitro. Cell Tissue Kinet. $20: 319-329,1987$.

5) Limeback, H.: Enamel protein and collagen production by cells subcultured from porcine tooth bud explants. Biochem. Cell Biol. 65: 698-709, 1987.

6) Fincham, A. G: A simple procedure for the isolation of a major amelogenin polypeptide component. Biochem. J. 181 : 171-175, 1979.

7) Fincham, A. G.: Changing amino acid profiles of developing dental enamel in individual human teeth and the comparison of the protein matrix of developing human and bovine enamel. Archs. Oral Biol. 25: 669-675, 1980.

8) Fincham., A. G., Belcourt, A. B., Termine, J. D., Butler, W. T. and Cothran, W. C.: Amelogenins. Sequence homologies in enamel-matrix proteins from three mammalian species. Biochem. J. 211 : 149-154, 1983.

9) Fincham, A. G., Hu, Y. Y., Lau, E., Pavlova, Z., Slavkin, H. C. and Snead, M. L. : Isolation and partial characterization of a human amelogenin from a single fetal dentition using HPLC techniques. Calcif. Tissue Intl. 47 : 105-111, 1990.

10) Snead, M. L., Luo, w., Lau, E. C. and Slavkin, H. C.: Spatial- and temporal- restricted pattern for amelogenin gene expression during mouse molar tooth organogenesis. Development 104: 77-85, 1988.

11) MacDougal, M., Zechner-David, M. and Slavkin, H. C.: Tissuespecific matrix production by dental epithelial and mesenchymal cell in vitro. J. Dent. Res. $70: 370,1991$.

12) MacDougal, M., Slavkin, H. and Zeichner-David, M. : Characterization of ameloblast-like cells using RTPCR. J. Dent. Res. 72: 203, 1993.

13) MacDougal, M., Theimann, F. and Diekwisch, T.: Enamel biomineralization in vitro in the absence of mineralized dentin. J. Dent. Res. 73: 112, 1994.

14) Kukita, A., Harada, H., Kukita, T., Inai, T., Matsuhashi, S. and Kurisu, K.: Primary and secondary culture of rat ameloblasts in serum-free medium. Calcif. Tissue Intl. $51:$ 393-398, 1992.

15) Chen, L. S., Couwenhoven, P., Hsu, D., Luo, W. and Snead, M.: Maintenance of amelogenin gene expression by transformed epithelial cells of mouse enamel organ. Archs. Oral Biol. 37: 771-778, 1992.

16) Den Besten, P. K., Mathews, C. H. E., Gao, C. and Li, W. : Primary culture and characterization of enamel organ epithelial cells. Connective Tissue Res. 38 : 3-8, 1997.

17) Krebsbach, P. H., Lee, S. K., Matsuki, Y., Kozak, C., A., Yamada, K., M. and Yamada, Y.: Full length sequence, localization and chromosomal mapping of ameloblastin. J. Biol. Chem. 271: 4431-4435, 1996.

18) MacDougall, M., Simmons, D., Gu, T. T., ForsmanSemb, K., Mardh, C. K., Mesbah, M., Forest, N., Krebsbach, P. H., Yamada, Y. and Berdal, A.: Cloning, characterization and immunolocalization of human ameloblastin. Eur. J. Oral Sci. 108: 303-310, 2000.

19) Morrison, S. J., Shah, N. M. and Anderson, D. J. : Regulatory mechanisms in stem cell biology. Cell 88 : 287-298, 1997.

20) Harada, H., Kettunen, P., Jung, H.-S., Mustonen, T., Wang, Y. A. and Thesleff, I.: Lacalization of putative stem cells in dental epithelium and their association with Notch and FGF singaling. J. Cell Biol. 147 : 105$120,1999$.

21) Fuchs, E. and Segre, J. A. : Stem cells: A new lease on life. Cell 100: 143-155, 2000.

22) Hu, C., Fukae, M., Uchida, T., Qian, Q., Zhang, C. H., Ryu, O. H., Tanabe, T., Yamakoshi, Y., Murakami, C., Dohi, N. et al.: Sheathlin : cloning, cDNA/ polypeptide sequences, and immunolocalization of porcine enamel sheath proteins. J. Dent. Res. 76 : 648- 
675, 1997.

23) Banks-Schlegel, S., P.: Keratin alterations during embryonic epidermal differentiation. J. Cell Biol. 93: 551-559, 1982.

24) Clausen, H., Moe, D., Buscard, D. and Dabelsteen, E. : Keratin proteins in human oral mucosa. J. Oral Pathol. 15: 36-42, 1986.

25) Gao, Z., Mackenzie, I. C., Williams D. M., Cruchley, A. T., Leigh, I. and Lane, E. B.: Patterns of Keratinexpression in rests of Malassez and periapical lesions. J. Oral Pathol. 17 : 178-185, 1988.

26) Tabata, J. M., Matsumura, T., Liu, J.-G., Wakisaka, S. and Kurisu, K.: Expression of cytokeratin 14 in ameloblast-lineage cells of the developing tooth of rat, both in vivo and in vitro. Archs Oral Biol. 41 : 1019-1027, 1996.

27) Domingues, M. G., Jaeger, M. M. M., Araujo, V. C. and Araujo, N., S.: Expression of cytokeratins in human enamel organ. Eur. J. Oral Sci. 108: 43-47, 2000.

28) Termine, J. D., Belcourt, A. B., Christner, P. J., Conn, K. M. and Nylen, M. U.: Properties of dissociatively extracted fetal tooth matrix proteins. 1. Principal molecular species in developing bovine enamel. J. Biol. Chem. 255 : 9760-9768, 1980.

29) Snead, M. L., Bringas, P., Bessen, C. and Slavkin, H.
C. : De novo gene expression detected by amelogenin gene transcript analysis. Dev, Biol. 104 : 255-258, 1984.

30) Inai, T., Kukita, T., Ohsaki, Y., Nagata, K., Kukita, A. and Kurisu, K.: Immunohistochemical demonstration of amelogenin penetration toward the dental pulp in the early stages of ameloblast development in rat molar tooth germs. Anat. Rec. 229: 259-270, 1991.

31) Nakamura, M., Bringas, P., Nanci, A., ZeichnerDavid. M., Ashdown, B. and Slavkin, H. C.: Translocation of enamel proteins from inner enamel epithelia to odontoblasts during mouse tooth development. Anat. Res. 238: 383-296, 1994.

32) Kettunen, P., Laurikkala, J., Itaranta, P., Vainio, S., Itoh, N. and Thesleff, I. : Associations of FGF-3 and FGF-10 with signaling networks regulating tooth morphogenesis. Dev. Dyn. 219: 322-332, 2000.

33) Thesleff, I., Partanen, A. M. and Vainio, S.: Epithelial-mesenchymal interactions in tooth morphogenesis: the role of extracellular matrix, growth factors, and cell surface receptors. J. Craniofac. Genet. Dev. Biol. 11 : 229-237, 1991.

34) Thesleff, I. and Shape, P.: Signalling networks regulating dental development. Mech. Dev. 67: 111-123, 1997. 